\title{
Lead Contamination and Microbial Lead Tolerance in Soils at Major Road Junctions in Benin City
}

\section{*ATUANYA, EI; OSEGHE, EO}

\author{
Department of Microbiology, University of Benin, P.M.B. 1154, Benin City. \\ E-Mail: atuei-g@yahoo.com. \\ Fax: 234-52-600273.
}

\begin{abstract}
Lead pollution and lead tolerance levels of microbes in soil at major road junctions in Benin City were investigated. Results revealed that distance from the road junctions affected the concentrations of lead in soil, as well as the microbial population density and types of microbes present in the soil. The highest concentrations of lead were recorded with soil samples obtained at 0 and $10 \mathrm{~m}$ distance closer to road junctions, while the lowest concentrations were recorded with soil samples obtained at $30 \mathrm{~m}$ distance away from road junctions. The highest concentrations recorded for lead, copper and iron were $32 \times 10^{1} \mathrm{mg} \mathrm{kg}^{-1}, 8 \times 10^{-1} \mathrm{mg} \mathrm{kg}^{-1} 6.3 \times 10^{-1}$ respectively. All these levels decreased rapidly as the distance from the road increased. Bacterial counts increased as the distance from the road junctions increased. While fungal counts decreased as distance from road junctions increased. Lead tolerance range of bacterial and fungal isolates was between 10 to $1000 \mathrm{mg}^{-1}$. Non-significant, negative correlation was found between lead concentration and microbal counts. The bacteria and fungi most frequently isolated at 0 and $10 \mathrm{~m}$ distance were Pseudomonas sp., Micrococcus sp., Bacillus sp., Candida utilis, Penicillium sp and the yeast Saccharromyces cerevisiae.@JASEM
\end{abstract}

The distribution of lead as a toxic pollutant has been the subject of concern since the advent of the antiknock lead additives in gasoline (Kuperman and Carreiro 1997: Chow and Earl, 1970). There has been much discussion on the emission of lead from automobile exhaust and its possible harmful effects on microbial and human populations. Lead, particularly from the use of leaded gasoline in vehicles is often the most important metal of anthropogenic origin deposited in soils. The average soil lead content has been found to be substantially higher in the soil samples nearer heavy traffic densities than comparable samples taken from distances away from these sources (Ludwig et al., 1965: Daines et al., 1972). Soil microorganisms are exposed heavily to automobile exhaust, and higher lead concentrations have been indicated to reduce microbial densities as a result of their toxicity. The effect of several metals in combination of on soil microbiota are largely unknown. Information on this aspect of metal toxicity is vital since no single metal dominates in an ecosystem. Benka-Coker (1991) demonstrated that the synergistic or antagonistic effects of combined metals (lead, zinc, copper, manganese, iron) showed that at lower concentrations, metals were antagonistic in their effects on Aspergillus niger and Candida lipolytica, but at increased concentrations they became synergistic. The downward movement of these metals as a result of leaching over a prolonged period may result in the contamination of ground water by these metals. Also, some of these metals may prevent or inhibit the uptake of useful soil minerals such as potassium phosphorous, nitrogen etc by plants (Atuanya et al., 1999). The increasing demand and production of heavy metals suggest their contacts with the environment in concentrations higher than those which natural processes could handle by themselves (Fagade and Adetutu, 1999). Studies on lead/heavy metal pollution and their microbial tolerance levels of lead, their solubilization and accumulation by two strains of Pseudomonas from battery manufacturing operations (Atuanya et al., 1999; Fagade and Adetutu, 1999).

This study examined lead contamination and lead tolerance levels of microbes in soils at major road junctions in Benin City. This study also assessed the toxicity and distribution of lead emission from the automobile exhaust to human and soil microbiota. The levels of copper and iron in the study area were equally evaluated to enable us see if the lead contamination can be attributed to heavy vehicular traffic at road junctions in Benin City.

\section{MATERIALS AND METHODS}

Sampling: Soil samples were collected from five different locations in the study area at distances of $0,10,20$, and 30 metres away from road junctions. Soil samples from each of the different locations at the same distance were mixed together to obtain composite samples. Soil samples were taken at depth of $0-15 \mathrm{~cm}$ below surface using soil auger. All samples were kept in clean sterile polythene bags, labeled accordingly and stored at room temperature. Soil samples for analyses were air-dried, sieved through a $2 \mathrm{~mm}$ sieve and weighed.

Microbial Isolation: Microorganisms were isolated from soil samples by pour plate technique on nutrient 
agar and potato dextrose agar containing $10 \mathrm{mg} 1^{-1}$, $100 \mathrm{mg}^{-1}$, 500mg $1^{-1}$, and $1000 \mathrm{mg}^{-1}$ concentrations of standard lead to show their tolerance to lead, as well as determine their population density in soils. Viable aerobic bacterial were isolated on nutrient agar plates. Fulcin (500 $\mathrm{mg}^{-1}$ ) was incorporated into the nutrient agar to inhibit fungal growth. Bacterial counts were obtained using serial dilution method. Serial dilution of the soil samples was prepared. Serial dilutions of tubes $10^{-3}$ and $10^{-4}$ were pourplated in $0.1 \mathrm{ml}$ volumes onto duplicate plates of nutrient agar. The plates were incubated at $28 \pm 2{ }^{\circ} \mathrm{C}$ for 48 hours. Developed colonies were counted using the Quebec colony counter. Viable colonies were picked from plates according to their different form, and purified by sub culturing onto fresh nutrient agar plates using the streak-plate technique. Isolated colonies which appeared on the plates were then transferred onto nutrient agar slants and stored as stock cultures for further test. The medium used for the isolation in and enumeration of fungi was potato dextrose agar into which chloramphenicol (100mg $1^{-}$ ${ }^{1}$ ) was incorporated to inhibit bacterial growth. The same procedure described earlier for bacterial isolation above was employed. The potato-dextrose agar plates were incubated at ambient temperature for 5 days to isolate fungi.

Characterization and Identification of Microbial Isolates: The bacterial isolates were examined for colonial morphology, cell micromorphological and biochemical characteristics. Gram stain reaction, spore stain, catalase test, methyl red test, motility test, indole test, oxidative fermentative utilization of glucose, $\mathrm{H}_{2} \mathrm{~S}$ production and other biochemical test were carried out with reference to Bergey's manual of determinative bacteriology, $8^{\text {th }}$ edition (Buchanan and Gibbon, 1995), and the manual for identification of medical bacteria (Cowan and steel, 1981). The macroscopic and microscopic (using the needle mount method) examinations of fungal isolates were carried out to determine their nature and colour on agar plates, shape of spore and mycelium with reference to the identification manual of Barnett and Hunter (1972), Larone (1976)

Table 1: Concentrations of heavy metals in soil samples

\begin{tabular}{lllll}
\hline $\begin{array}{l}\text { Sample } \\
\text { location }\end{array}$ & $\begin{array}{l}\text { Distance } \\
\text { from } \\
\text { location } \\
(\mathrm{m})\end{array}$ & $\mathrm{Pb}$ & $\begin{array}{l}\text { Metals } \\
\mathrm{Cu}\end{array}$ & $\mathrm{Fe}$ \\
\hline Uwasota & 0 & $8.00 \pm 0.2$ & $0.0 \pm 0.0$ & $6.3 \times 10^{-2} \pm 1.1$ \\
& 10 & $3.00 \pm 0.5$ & $0.0 \pm 0.0$ & $2.4 \times 10^{-2} \pm 0.8$ \\
& 20 & $2.00 \pm 0.1$ & $0.00 \pm 0.0$ & $5 \times 10^{-3} \pm 0.1$ \\
& 30 & $2.00 \pm 1.1$ & $8 \times 10^{-3} \pm 0.1$ & $7.3 \times 10^{-2} \pm 0.5$ \\
Ikpokpan & 0 & $32.00 \pm 0.8$ & $0.00 \pm 0.7$ & $1.1 \times 10^{-2} \pm 1.2$ \\
& 10 & $11.00 \pm 0.7$ & $2 \times 10^{-3} \pm 0.8$ & $1.2 \times 10^{-2} \pm 0.3$ \\
& 20 & $4.00 \pm 0.3$ & $0.00 \pm 0.7$ & $3 \times 10^{-2} \pm 0.8$ \\
Ramat Park & 0 & $2.00 \pm 0.9$ & $1 \times 10-3 \pm 0.3$ & $5 \times 10^{-3} \pm 0.4$ \\
& 0 & $24.00 \pm 0.7$ & $1 \times 10^{-3} \pm 0.9$ & $7 \times 10^{-3} \pm 1.0$ \\
& 20 & $4.00 \pm 1.2$ & $2 \times 10^{-3} \pm 0.1$ & $8 \times 10^{-3} \pm 0.2$ \\
Ehaekpen & 0 & $2.00 \pm 1.1$ & $2 \times 10^{-3} \pm 0.7$ & $0.00 \pm 0.0$ \\
& $0.00 \pm 0.0$ & $3 \times 10^{-3} \pm 0.4$ & $1 \times 10^{-3} \pm 0.6$ \\
& 10 & $10.00 \pm 0.2$ & $2 \times 10^{-3} \pm 0.7$ & $2 \times 10^{-2} \pm 0.3$ \\
& 20 & $7.00 \pm 0.3$ & $5 \times 10^{-3} \pm 0.8$ & $1.5 \times 10^{-2} \pm 0.8$ \\
Botanical & 30 & $4.00 \pm 0.6$ & $2 \times 10^{-3} \pm 0.1$ & $7.2 \times 10^{-2} \pm 0.6$ \\
garden & Control & $2.00 \pm 0.5$ & $5 \times 10^{-3} \pm 1.0$ & $5 \times 10^{-3} \pm 0.5$ \\
& & & $2 \times 10^{-3} \pm 0.2$ & $1 \times 10^{-3} \pm 0.1$ \\
\hline
\end{tabular}

NB: Values are $\mathrm{mg} \mathrm{kg}^{-1}$ soil and block means of three replicates.

Growth of Microbial Isolates at Different Concentrations of Standard Lead: Microorganisms were examined for their ability to accumulate lead from dilute solution (i.e their lead tolerance levels) by growing them on media containing different concentrations of lead. One gram of sterile lead sulphide (PbS) was dissolved in distilled water in a $1000 \mathrm{ml}$ volumetric flask and was made up to the mark with distilled water. The resultant solution containing $1000 \mathrm{mgL}^{-1}$ was used as stock solution. A $10 \mathrm{ml}$ sample of the stock solution was pippetted into a $1000 \mathrm{ml}$ flask. This was diluted with distilled water to give a $10 \mathrm{mgL}^{-1}$ solution of lead. Also, solutions containing 100 and $500 \mathrm{mgL}^{-1}$ lead were similarly prepared. About $50 \%$ of the different concentrations of standard lead solution were incorporated in the nutrient agar and potato-dextrose agar before inoculating the plates with serially diluted solution of soil samples. At the end of their incubation periods, bacterial and fungal counts were recorded. 
Determination of Levels of some Heavy Metal Contents in Soil Samples: Soil samples were analysed for lead, copper and iron by atomic absorption spectrophotometer (Model 200 A Buck Scientific). For measurement of the total concentration of the heavy metals, the soil samples were digested by double acid extraction method (Black et al., 1985). A double acid solution was prepared by adding $0.7 \mathrm{ml}$ of concentrated sulphuric acid to $8 \mathrm{ml}$ of a $6 \mathrm{M}$ hydrochloric acid in a $1000 \mathrm{ml}$ volumetric flask, this was made to the mark with distilled water. A $6 \mathrm{~g}$ sample of soil was placed in $250 \mathrm{ml}$ plastic bottle with $60 \mathrm{ml}$ of the double acid solution added. The content of the bottle was shaken for one hour and then filtered. The filtrates were analysed for lead, copper and iron. The concentrations of each metal in the soil samples were calculated by extrapolation from standard curves of absorbance against concentrations in ppm (i.e mg kg$\left.{ }^{1}\right)$.

Chemical and Physical Analysis of Soil Samples: Representative soil samples were analysis for physico-chemical properties using standard methods (APHA, 1995). $\mathrm{pH}$ of soil samples was determined with a pH meter (Udo and Ogunwale, 1978), percent organic carbon and percent organic matter by the Walkley and Black (1934) procedure, while total nitrogen was determined by the Kjeldahi method (Udo and Ogunwale, 1978). Particle size determination of soil samples was done by the hydrometer method (Udo and Ogunwale, 1978).

Statistical Analysis: A correlation coefficient analysis between lead concentrations with microbial counts, and the various physico-chemical parameters, as well as between $\mathrm{pH}$ and microbial counts were performed. A two way factorial analysis of variance was carried out to test the effect of distance from road junctions and the effect of different concentration of lead on microbial population density at different locations (Zar, 1984). Also, Kolmogorov - Smirnov test was conducted to determine the uniform distribution of lead concentration in soil samples collected from the different

Table 2: Total bacterial counts of soil samples plated on nutrient agar using different concentrations of lead at room temperature (cfu ml $\left.\mathbf{~ m}^{-1}\right)$

\begin{tabular}{|c|c|c|c|c|c|c|}
\hline \multirow[t]{2}{*}{$\begin{array}{l}\text { Sample } \\
\text { location }\end{array}$} & \multirow{2}{*}{$\begin{array}{l}\text { Distance } \\
\text { from } \\
\text { location } \\
\text { (m) }\end{array}$} & \multicolumn{5}{|c|}{ Concentration of lead $\mathrm{mgl}^{-1}$} \\
\hline & & 0 & 10 & 100 & 1000 & \\
\hline \multirow[t]{4}{*}{ Uwasota } & 0 & $2.0 \times 10^{5}$ & $18.5 \times 10^{4}$ & $4^{4} \quad 1.7 \times 10^{5}$ & $12.5 \times 10^{4}$ & $8 \times 10^{4}$ \\
\hline & 10 & $2.9 \times 10^{5}$ & $2.5 \times 10^{5}$ & $1.2 \times 10^{5}$ & $1.0 \times 10^{5}$ & $6 \times 10^{4}$ \\
\hline & 20 & $3.5 \times 10^{5}$ & $27.5 \times 10^{4}$ & $1.6 \times 10^{5}$ & $8.5 \times 10^{4}$ & $7.5 \times 10^{4}$ \\
\hline & 30 & $3.9 \times 10^{5}$ & $3.3 \times 10^{5}$ & $12.5 \times 10^{4}$ & $9 \times 10^{4}$ & $5.5 \times 10^{4}$ \\
\hline \multirow[t]{4}{*}{ Ikpokpan } & 0 & $1.8 \times 10^{5}$ & $1.5 \times 10^{5}$ & $14.5 \times 10^{4}$ & $11.5 \times 10^{4}$ & $8.5 \times 10^{4}$ \\
\hline & 10 & $2.3 \times 10^{5}$ & $21.5 \times 10^{4}$ & $1.8 \times 10^{5}$ & $1.1 \times 10^{5}$ & $6 \times 10^{4}$ \\
\hline & 20 & $2.5 \times 10^{5}$ & $2.2 \times 10^{5}$ & $18.5 \times 10^{4}$ & $10.5 \times 10^{4}$ & $6.5 \times 10^{4}$ \\
\hline & 30 & $2.8 \times 10^{5}$ & $2.6 \times 10^{5}$ & $12.5 \times 10^{4}$ & $9 \times 10^{4}$ & $6.5 \times 10^{4}$ \\
\hline \multirow{4}{*}{$\begin{array}{l}\text { Ramat } \\
\text { Park }\end{array}$} & 0 & $1.5 \times 10^{5}$ & $13.5 \times 10^{4}$ & $8.5 \times 10^{5}$ & $1.1 \times 10^{5}$ & $6 \times 10^{4}$ \\
\hline & 10 & $2.8 \times 10^{5}$ & $2.6 \times 10^{5}$ & $15.5 \times 10^{4}$ & $1.1 \times 10^{5}$ & $8 \times 10^{4}$ \\
\hline & 20 & $3.8 \times 10^{5}$ & $3.6 \times 10^{5}$ & $15.5 \times 10^{4}$ & $7.5 \times 10^{4}$ & $4.5 \times 10^{4}$ \\
\hline & 30 & $3.8 \times 10^{5}$ & $3.6 \times 10^{5}$ & $2.1 \times 10^{5}$ & $1.3 \times 10^{5}$ & $6.5 \times 10^{4}$ \\
\hline \multirow[t]{4}{*}{ Ehaekpen } & 0 & $1.5 \times 10^{5}$ & $2.1 \times 10^{5}$ & $17.5 \times 10^{4}$ & $12.5 \times 10^{4}$ & $9.5 \times 10^{4}$ \\
\hline & 10 & $1.6 \times 10^{5}$ & $1.4 \times 10^{5}$ & $1.3 \times 10^{5}$ & $9 \times 10^{4}$ & $5.5 \times 10^{4}$ \\
\hline & 20 & $2.6 \times 10^{5}$ & $2.1 \times 10^{5}$ & $1.9 \times 10^{5}$ & $1.1 \times 10^{5}$ & $8.5 \times 10^{4}$ \\
\hline & 30 & $2.9 \times 10^{5}$ & $2.6 \times 10^{5}$ & $21.5 \times 10^{4}$ & $15.5 \times 10^{4}$ & $13.5 \times 10^{4}$ \\
\hline $\begin{array}{l}\text { Botanical } \\
\text { garden }\end{array}$ & Control & $6.0 \times 10^{5}$ & $5.5 \times 10^{5}$ & $2.4 \times 10^{5}$ & $1.8 \times 10^{5}$ & $12.5 \times 10^{4}$ \\
\hline
\end{tabular}

\section{RESULTS}

Table 1 shows the total concentrations of lead, copper and iron. From the table, the highest concentrations of lead were recorded in soil samples collected at 0 and 10 meters closer to road junctions, while the lowest concentration were recorded in samples collected at 30 meters away from road junctions. The highest concentration recorded for lead, copper and iron were $32 \times 10^{1} \mathrm{mg} \mathrm{kg}^{-1}, 8 \times 10^{-3} \mathrm{mg} \mathrm{kg}^{-1}$ and $6.3 \mathrm{x}$ $10^{2} \mathrm{mg} \mathrm{kg}^{-1}$ respectively. The average concentration of lead is substantially higher than concentrations of copper and iron in soil samples. When the concentration of lead $\left(2.00 \mathrm{mg} \mathrm{kg}^{-1}\right)$ at the control station was compared with those at road junction and few meters distance from road junctions, it showed that the soils at road junctions were more contaminated with lead. These results suggest that the soils around major road junctions in Benin City are contaminated primarily with lead from motor exhaust as a result of heavy vehicular traffic densities. Tables 
2 and 3 show the total viable counts for bacteria and fungi isolated from soil samples at major road junctions. Results from the tables revealed that bacterial counts were lower in the soil samples near road junctions than comparable samples taken from distance away from the road junctions (see the 0 concentration columns). While fungal counts were higher in soil samples near road junctions than comparable samples away from road junctions. This is because fungi grow better under acidic condition (low $\mathrm{pH}$ ) found around road junctions (see Table 4).

Table 3: Total fungal counts of soil samples plated on potato dextrose agar at room temperature using different concentrations of lead (cfu $\mathrm{ml}^{-1}$ )

\begin{tabular}{|c|c|c|c|c|c|c|}
\hline \multirow{2}{*}{$\begin{array}{l}\text { Sample } \\
\text { location }\end{array}$} & \multirow{2}{*}{$\begin{array}{l}\text { Distance from } \\
\text { location (m) }\end{array}$} & \multicolumn{5}{|c|}{ Concentrations of Lead $\left(\mathrm{mgl}^{-1}\right)$} \\
\hline & & 0 & 10 & 100 & 500 & 1000 \\
\hline \multirow[t]{4}{*}{ Uwasota } & 0 & $5 \times 10^{3}$ & $8.5 \times 10^{3}$ & $9.5 \times 10^{3}$ & $9 \times 10^{3}$ & $5.5 \times 10^{3}$ \\
\hline & 10 & $4 \times 10^{3}$ & $6 \times 10^{3}$ & $6 \times 10^{3}$ & $3.5 \times 10^{3}$ & $3 \times 10^{3}$ \\
\hline & 20 & $3 \times 10^{3}$ & $4.5 \times 10^{4}$ & $4 \times 10^{3}$ & $3 \times 10^{3}$ & $2.5 \times 10^{3}$ \\
\hline & 30 & $1.0 \times 10^{4}$ & $1.0 \times 10^{3}$ & $3 \times 10^{3}$ & $2 \times 10^{3}$ & $2 \times 10^{3}$ \\
\hline \multirow[t]{4}{*}{ Ikpokpan } & 0 & $6 \times 10^{3}$ & $9 \times 10^{3}$ & $4 \times 10^{3}$ & $3.5 \times 10^{3}$ & $2.5 \times 10^{3}$ \\
\hline & 10 & $5 \times 10^{3}$ & $7 \times 10^{3}$ & $4 \times 10^{3}$ & $3 \times 10^{3}$ & $2 \times 10^{3}$ \\
\hline & 20 & $5 \times 10^{3}$ & $7 \times 10^{3}$ & $4 \times 10^{3}$ & $2.5 \times 10^{3}$ & $2 \times 10^{3}$ \\
\hline & 30 & $3 \times 10^{3}$ & $4 \times 10^{3}$ & $2.5 \times 10^{3}$ & $2 \times 10^{3}$ & $1 \times 10^{3}$ \\
\hline \multirow[t]{4}{*}{ Ramat Park } & 0 & $8 \times 10^{3}$ & $9 \times 10^{3}$ & $8.5 \times 10^{3}$ & $8 \times 10^{3}$ & $7 \times 10^{3}$ \\
\hline & 10 & $8 \times 10^{3}$ & $6 \times 10^{3}$ & $6 \times 10^{3}$ & $4 \times 10^{3}$ & $2 \times 10^{3}$ \\
\hline & 20 & $8 \times 10^{3}$ & $6 \times 10^{3}$ & $5 \times 10^{3}$ & $3 \times 10^{3}$ & $2 \times 10^{3}$ \\
\hline & 30 & $6 \times 10^{3}$ & $5 \times 10^{3}$ & $4 \times 10^{3}$ & $2 \times 10^{3}$ & $1 \times 10^{3}$ \\
\hline \multirow{4}{*}{ Ehaekpen } & 0 & $7 \times 10^{3}$ & $7 \times 10^{3}$ & $4 \times 10^{3}$ & $3 \times 10^{3}$ & $2.5 \times 10^{3}$ \\
\hline & 10 & $6 \times 10^{3}$ & $5 \times 10^{3}$ & $3.5 \times 10^{3}$ & $3 \times 10^{3}$ & $2 \times 10^{3}$ \\
\hline & 20 & $5 \times 10^{3}$ & $4.5 \times 10^{3}$ & $3 \times 10^{3}$ & $2.5 \times 10^{3}$ & $2 \times 10^{3}$ \\
\hline & 30 & $4 \times 10^{3}$ & $4 \times 10^{3}$ & $3 \times 10^{3}$ & $2 \times 10^{3}$ & $2 \times 10^{3}$ \\
\hline $\begin{array}{l}\text { Botanical } \\
\text { garden }\end{array}$ & Control & $5 \times 10^{3}$ & $5 \times 10^{3}$ & $3 \times 10^{3}$ & $3 \times 10^{3}$ & $2 \times 10^{3}$ \\
\hline
\end{tabular}

The heterotrophic bacterial counts range from $1.5 \mathrm{x}$ $10^{5}$ to $3.9 \times 10^{5} \mathrm{cfu} \mathrm{ml}^{1}$ while that of fungi range from $3 \times 10^{3}$ to $8 \times 10^{3} \mathrm{cfu} \mathrm{ml}^{-1}$, thus indicating that the samples were contaminated by $\mathrm{Pb}$ toxic to most of the indigenous microorganisms. It was equally observed that the growth of microorganisms on media containing different concentrations of Lead showed that these microorganisms were capable of accumulating lead from dilute solutions of the heavy metal. The bacteria isolates identified were Pseudomonas sp., Klebsiella sp., Escherichia coli, Bacillus cereus, Bacillus licheniformis, Micrococcus sp., Escherichia coli, Bacillus cereus, Bacillus licheniformis, Micrococcus sp., Staphylococcus aureus, Proteus sp. and Flavobacterium deorans. While the fungi isolates include Fusarium sp., Penicillium sp., Aspergillus flavus, Candida utilis, Trichoderma sp. and the yeast Saccharomyces cerevisiae.

The highest bacterial and fungal counts were recorded on plates containing $10 \mathrm{mg} 1^{1}$ of $\mathrm{Pb}$, and as the concentration increased gradually to $1000 \mathrm{mg} 1^{-}$ ${ }^{1}$,there was a sharp decrease in microbial population. However, $\mathrm{Pb}$ became toxic to both bacterial and fungal isolates between the range of $10 \mathrm{mg}^{-1}$ to $1000 \mathrm{mg} 1^{-1}$. Table 4 shows the values of the chemical characteristics of soil samples at the different locations. The values were determined before soil samples were treated with various concentrations of lead. The $\mathrm{pH}$ values were observed to be lower in soil samples closer to road junctions (i.e 0 and $10 \mathrm{~m}$ distance). Reducing $\mathrm{pH}$ values have been reported to cause reductions in counts of most bacterial species and increase in fungal counts. Though metal mobilization has been attributed to low $\mathrm{pH}$, acidic $\mathrm{pH}$ may not necessarily lead to higher metal uptake than in neutral or higher $\mathrm{pH}$ values (Huang et al., 1988). This is because, at low $\mathrm{pH}, \mathrm{H}$ may compete with $\mathrm{Pb}$ ions for metal ligands on cells (Blackwell et al., 1995). The presence of lead may also cause decrease in viable counts as a result of free $\mathrm{Pb}$ ion toxicity (Hughes and Poole, 1989). The texture of the different soil samples used in this study was loamy sand. A non-significant, negative correlation was found between lead concentrations and microbial counts $(P>0.05)$. Nevertheless, the correlation result revealed that increase in lead concentration resulted to a decrease in microbial population density. Results of the analysis of variance showed that both concentration of lead and distance from road junctions significantly affected the bacterial counts of soil samples collected from Uwasota, Ikpokpan, Ramat Park and Ehaekpen junctions $(P<0.05)$, i.e., bacterial counts increased as one moves further away from road junctions, and counts reduced with increase in lead concentration. Fungal counts were only significantly affected by distance from road junction at Uwasota junction. For Ikpokpan junction, concentration of lead and distance from road junction had no significant effect on fungal counts ( $\mathrm{P}>0.05$ ). Only distance from road junction had significant 
effect on fungal counts at Ramat Park junction, while only concentration of lead had significant effect on fungal counts. The Kolmogorov - Smirnov test revealed that the concentrations of lead along the distance from road junction were significant $(\mathrm{P}<$ 0.05) for Uwasota and Ramat Park junctions only. Ikpokpan and Ehaekpen junctions had uniform distribution of lead along the distance.

Table 4: Chemical characteristics of soil samples (Mean values, $n=3$ )

\begin{tabular}{lllllll}
\hline $\begin{array}{l}\text { Sample } \\
\text { Location }\end{array}$ & $\begin{array}{l}\text { Distance from } \\
\text { location }(\mathrm{m})\end{array}$ & $\mathrm{pH}$ & $\begin{array}{l}\text { E.C. } \\
\left(\mu \mathrm{s} / \mathrm{CM}^{3}\right)\end{array}$ & $\begin{array}{l}\text { Organic } \\
\text { carbon } \\
(\%)\end{array}$ & $\begin{array}{l}\text { Organic } \\
\text { matter } \\
(\%)\end{array}$ & $\begin{array}{l}\text { Total } \\
\text { nitrogen } \\
(\%)\end{array}$ \\
\hline Uwasota & 0 & & & 0.29 & 0.50 & 0.02 \\
& 10 & 5.62 & 1175 & 1.09 & 0.95 & 0.06 \\
& 20 & 6.56 & 535 & 0.55 & 1.85 & 0.03 \\
Ikpokpan & 0 & 7.16 & 399 & 1.70 & 2.94 & 0.09 \\
& 10 & 7.25 & 161.3 & 0.26 & 0.45 & 0.04 \\
& 20 & 6.30 & 336 & 0.91 & 1.38 & 0.013 \\
Ramat & 0 & 644 & 222 & 0.80 & 1.57 & 0.05 \\
Park & 30 & 7.67 & 119.3 & 1.00 & 1.73 & 0.05 \\
& 10 & 7.70 & 126.6 & 0.50 & 0.86 & 0.03 \\
& 20 & 6.93 & 92.4 & & & \\
Ehaekpen & 0 & & & & & \\
& 30 & 7.43 & 117.7 & 0.50 & 0.86 & 0.09 \\
& 10 & 7.93 & 120 & 0.50 & 0.86 & 0.03 \\
& 20 & 8.08 & 200 & 1.70 & 2.94 & 0.10 \\
Botanical & Control & 7.47 & 160 & 0.95 & 1.64 & 0.03 \\
garden & & 7.94 & 150 & 1.45 & 2.51 & 0.073 \\
\hline
\end{tabular}

\section{DISCUSSION}

The isolation of bacteria and fungi from soil samples at different road junctions is an indication that the isolated microorganisms are capable of growing in the presence of toxic heavy metals like lead (Tornabene and Edward, 1972). Table 2 and 3 reflect the concentration levels of lead at which most of the microbial cells were inhibited. Some of these concentrations are toxic to microbes even at a lower concentration. Some are also beneficial at certain levels or concentrations (Bull et al., 198: Boularbah et al., 1992). The results revealed the inhibition of cells in the media used, which even reflect on the total number of cell counts on plates containing higher concentrations of lead as compared to cell count on plates without lead. This is evident by adsorption of lead into the cells up to a certain level at which they can no longer tolerate. Decreased physiological activity is a common response to heavy metal toxicity (Dean - Ross, 1991; Mc Eldowney, 1994). This was reflected in the results in which microbial counts increased on plates without lead and decreased as the concentrations of lead increased. Differences in tolerance among the isolates might be explained by the differences in metal accumulation in the cells.

The lead contaminated soils contained lower levels of microbial biomass than the control soil. This was not necessarily a direct effect of lead toxicity because the soils did not have plant communities; therefore, the lack of organic matter input could have reduced the microbial populations. Kuperman and Carreiro (1997) reported that soils contaminated with heavy metals had significantly less plant biomass and this affect the microbial population levels in the soils.

The colony counts of the microorganisms on media containing different concentrations of lead showed that these microorganisms are capable of accumulating lead from dilute solutions of heavy metals (Norris and Kelly, 1979). Microbial population density decreased as the concentration of lead increased to $1000 \mathrm{mg}^{-1}$. This decrease is due to the fact that high concentration of lead are toxic to most of the microbes. This corresponds with the suggestion of Benka - Coker (1991), that all elements can in fact be toxic to microorganism at sufficiently high concentration. The findings of this research revealed that higher lead concentration in soils at major road junction in Benin City, due mainly to emission of lead from automobile exhaust has toxic effect on microorganisms inhabiting the soil.

\section{REFERENCES}

American Public Health Association (1995). Standard Methods for the Examination of Water and Waste water. $19^{\text {th }}$ Ed. American Public health Association, Washington, DC. 1134pp.

Atuanya, E.I, Obuekwe, C.O. Ehigie, S.O (1999). Microbial studies and lead tolerance levels of 
microbes in lead accumulator dumps. Jour. Env. Sci. and Health 2(1): $8-13$.

Barnett. H.L. Hunter, B.B (1972). Illustrated Genera of Imperfect Fungi. $3^{\text {rd }}$ Ed. Bourges Publishing Co. Minneapolis 241pp.

Benka Coker, M.O. (1991). Studies on the Effects of Crude Oil and the Microbial Populations at the Kokori Flare Site, Bendel State, Nigeria. Ph.D. Thesis, University of Benin, Benin City. 83pp.

Black C.A, Evans, D.D, White J.C, Ensminger, L.E, Clark, F.E (1983). Methods of Soil Analysis (Part 1 and 2). Americaln Society of Agronomy Inc. Publishers. Wisconsin, U.S.A. pp $76-186$.

Blackwell, K.J, Singleton, T; Tobin, J (1995). Metal cation uptake by yeast, A review Appl. Microbiol. Biotechnol.43: 579 - 584.

Boularbah, A, Morel, J.L., Bitton, G; Guckert, A (1992). Cadmium biosorption and toxicity to six cadmium - resistant Gram - positive bacteria isolated from contaminated soil. Environ. Toxicol. Water Qual. 7: 246 - 301.

Buchanan R.E, Gibbons, N.E (1995). Bergey’s Mannual of Determinative Bacteriology. $8^{\text {th }}$ Ed. Williams, Wilkens Co., Baltimore. 1268pp.

Bull, A.T. Ellwood, D.C, Ratledge, C (1981) Microbial Technology. Cambridge University Press. 297pp.

Chow, J.T; Earl, L.J. (1970). Lead aerosol in the atmosphere. Sci. 169: 577 - 580.

Cowan, S.T; Steel, K.J. (1981). Manual for identification of Medical Bacteria $2^{\text {nd }}$ Ed. Cambridge University Press, London. 217pp.

Danies, R.H, Smith, D.W, Felicianoh, A, Trout, J.R. (1972). Air levels of lead inside and outside of homes. Industr. Med. 41: 26-27.

Dean-Ross, D (1991). Effect of combined treatment of zinc and $\mathrm{pH}$ on attached bacterial abundance and activity. Can. J. Microbiol. 37: 491 - 496.
Fagade, O.E; Adetutu, E.M (1999). Lead solubilizaiton and accumulation by two strains of Pseudomonas species obtained from a battery manufacturing factory's effluent. Nigeria Jour. Microbiol. 13: 39 - 46.

Huang C.P, Westman, D, Quirk, K; Huang, J.P. (1988). The removal of $\mathrm{cd}^{2+}$ from dilute aqueous solution f fungal absorbers. Water sci. Tech.20: $369-376$.

Hughes, M, Poole, R (1989). Metals and Microorganisms. Chapman and Hall U.K 396PP.

Kuperman, R.G; Carreiro, M.M. (1997). Soil heavy metal concentrations, microbial biomass and enzyme activities in a contaminated grassland ecosystem. Soil Biol. Biochem. 29: 179 - 190.

Larone D.H; (1976) Medically important Fungi; a guide to identification. Herper; Row, Hagerstown M.D. pp. 3-25.

Ludwig, J.H, Diggs, D.R., Resselberg, H.I; Mega, J.A. (1965). Survey on lead in the atmosphere of three urban communities. Am. Ind. Hyg. Assoc. J.26: $270-271$.

Mc Eldowney, S (1994). Effect of cadmium and zinc on attachment and detachment interaction of Pseudomonas fluorescents $\mathrm{H}^{2}$ with glass. Appl. Environ. Microbiol. 28: 2759 - 2765.

Norris, P.R; Kelly, D.P. (1979). Accumulation of metals by bacteria and yeasts. Dev. Ind. Microbiol. 20: 299 - 308.

Tornabene, T; Edwards, H (1972). Microbial uptake of lead. Sci. 179: $1334-1335$.

Udo, E.J; Ogunwale, J.A. (1978). Laboratory manual for the analysis of soil, plant and water samples. University of Ibadan. 109 pp.

Walkley, A; Black. I.A. (1934). Active or decomposable organic matter in the soil. Soil Sci. 37: $29-38$.

Zar, J.H. (1984). Biostatistical Analysis $2^{\text {nd }}$ Ed. Prentice Hall, New Jersey. 717 pp. 